\title{
Fostering Problem-Solving in a Virtual Environment
}

\author{
Danielle Morin \\ Concordia University, John \\ Molson School of Business, \\ Montreal, Quebec, Canada \\ danielle.morin@concordia.ca
}

\author{
Jennifer D. E. Thomas \\ Pace University, Ivan \\ Seidenberg School of CSIS, \\ New York, NY
}

ithomas@pace.edu

\section{Raafat George Saadé \\ Concordia University, John Molson School of Business, Montreal, Quebec, Canada}

\author{
raafat.saade@concordia.ca
}

\begin{abstract}
This article investigates students' perceptions of the relationship between Problem-Solving and the activities and resources used in a Web-based course on the fundamentals of Information Technology at a university in Montreal, Canada. We assess for the different learning components of the course, the extent of perceived problem-solving skills acquisition including research, creativity and critical thinking skills. The course entailed two categories of learning, namely resources-based and interactive components. The study aimed at answering the following questions: 1) To what extent do students understand the definitions of Problem-solving, Research, and Creative Idea Generation skills, and Critical Thinking skills? (2) What is the relative contribution of the various learning components (activities and resources) of the course to the perceived acquisition of Problem-Solving, Research, and Creative Idea Generations skills, and Critical Thinking skills; (3) Is the understanding of the definitions correlated with the perceived contributions of the learning components (activities and resources) of the course to the skills development? (4) To what extent is perceived Problem-solving skill acquisition explained by the acquisition of the other three skills?
\end{abstract}

Keywords: critical thinking skills, information technology, problem-solving, web-based learning

Material published as part of this publication, either on-line or in print, is copyrighted by the Informing Science Institute. Permission to make digital or paper copy of part or all of these works for personal or classroom use is granted without fee provided that the copies are not made or distributed for profit or commercial advantage AND that copies 1) bear this notice in full and 2) give the full citation on the first page. It is permissible to abstract these works so long as credit is given. To copy in all other cases or to republish or to post on a server or to redistribute to lists requires specific permission and payment of a fee. Contact Publisher@,InformingScience.org to request redistribution permission.

\section{Introduction}

The research presented here concerns the role that web-based learning may be able to play in students' perceived acquisition of problem-solving skills from the activities and resources in an entirely online course. Prior research has indicated that the activities and resources in a course can impact students' percep- 
tions of their acquisition of various higher-order learning skills, including problem-solving (Morin, Thomas \& Ly, 2014; Morin, Thomas, \& Saadé, 2012; Saadé, Morin \& Thomas, 2012; Thomas \& Morin, 2010). Additionally, Davis (1989) has shown that user's intention to use a system is tied to their perceptions, while Keengwe (2007) and Koohang \& Durante (2003) found that a relationship exists between students' personal computer proficiency and students' perceptions of the effect of computer technology to improve their learning. Song, Singleton, Hill, \& Koh (2004) focused on students' perceptions as a way to improve online or distance learning. Perceptions are, therefore, important considerations when integrating technology into learning, especially virtual learning.

Some level of web-based learning has now become the norm rather than the exception. Even classes that principally use a traditional classroom, lecture approach to delivery often integrate some level of web-based learning via course management systems, often referred to as blended learning. At the other end of the spectrum of delivery methods is the completely online, virtual delivery of course content, which is the focus of the research presented here. This delivery method is expected to have some impact on the students' ability to acquire problem-solving skills deemed essential for navigating life and achieving successful career paths.

A distinction has to be made between Problem-Solving and Problem-Based Learning. ProblemBased Learning is a teaching method that uses problems specifically designed to foster problemsolving skills, among other higher-order thinking skills (Baturay \& Bay, 2010; Liu, et al. 2014; Tsai \& Chiang, 2013). Problem-Solving, in contrast, is the outcome that is achieved by any teaching method employed, which may or may not include problem-based learning.

Compared to problem-based learning, the body of knowledge for problem-solving in higher education is significantly less. In this paper the focus is on problem-solving defined as "deriving alternatives and solutions for complex problems/ issues with incomplete information", as supported by research skills, creativity, and critical thinking, regardless of teaching method. This definition is based on a number of researchers who have built on each other's work and around which there is much overlapping of ideas. According to Hennessey, McCormack, \& Murphy (1993) and ITS Education Asia (2014), problem-solving requires a controlled mixture of analytical and creative thinking. In Bloom's Taxonomy of learning, problem-solving encompasses analysis, synthesis, evaluation, and in the revised taxonomy it encompasses analyzing, evaluating, and creating (Anderson \& Krathwohl, 2001; Bloom \& Krathwohl, 1956). Missing from these and other taxonomies, however, is the requisite need for researching the problem and the potential solutions (Jonassen, 1997, Saadé et al., 2012). Before doing any sort of analysis, synthesis, or evaluation, it is necessary to either proactively search out problems and solutions before they occur or to conduct research surrounding particular problems that do occur. These are articulated in Land \& Green (2000) who are referencing Moore, 1995, as:

...identifying information needs; locating corresponding information resources; extracting and organizing information from each source; and synthesizing information from a variety of sources into cogent, productive uses (Moore, 1995). (p.45)

In their case study, Oldenburg \& Hung (2010) found nursing students focused mostly on information gathering, with less attention to problem recognition, construction of meaning, and problem resolution.

Problem-solving, then, can be viewed as an umbrella term, supported by a tripod of skills encompassing research, creative idea generation (referred to interchangeably as creativity throughout the paper for simplicity), and critical thinking (Thomas, 2001), but this may not tell the whole story as shown in Figure 1. 


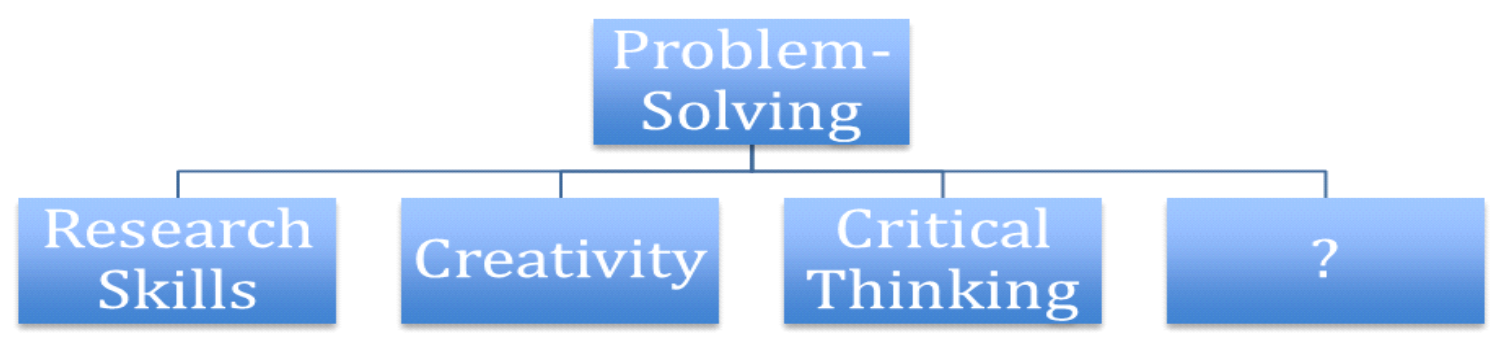

Figure 1. Problem-Solving Tripod or Four-legged Stool?

This study provides two significant contributions. (1) At a macro level, it provides an understanding of the relationship of problem-solving to its proposed sub-components of research, creative idea generation, and critical thinking skills in the online learning context (higher education); (2) At a micro level, it identifies the kinds of resources and activities that foster / require these problem-solving skills.

With this knowledge, practitioners (teachers and online courses designers) can design and implement better online (web-based) courses by integrating learning tools to foster the development of problem-solving, and associated research and creative idea generation skills, and critical thinking skills.

\section{Literature Review}

It goes without saying that the purpose of higher education is to provide students with the capacity for higher-order thinking and learning. This does not change when the medium of delivery changes. According to Lewis and Smith (1993), higher-order thinking:

...occurs when a person takes new information and information stored in memory and interrelates and/or rearranges and extends this information to achieve a purpose or find possible answers to perplexing situations. A variety of purposes can be achieved through higher-order thinking... Deciding what to believe; deciding what to do; creating a new idea, a new object, or an artistic expression; making a prediction; and solving a non-routing problem. (p.136)

Summarizing the ideas of heavyweights in the field, such as Piaget, Bloom, Gagne, Marzano, Glaser, Vygotsky, Haladyna, \& Gardner, the authors King, Goodson, \& Rohani (1998) propose that higher-order thinking includes critical, logical, reflective, metacognitive, and creative thinking. Developing these skills requires distinguishing important from unimportant information, integration and interpretation of information, critical thinking and problem-solving, and time and effort management. Lewis \& Smith (1993) suggest it includes critical thinking, problem-solving, decision-making, and creative thinking. In her review of the literature, Collins (2014) recognizes three schools of definitions of higher-order learning provided by Brookhart (2010): those who view it as transfer - being able to apply what has been learned to new situations or conditions, those who view it as critical thinking - being able to make sound decisions and exercise reasoned judgment, and those who view it as problem-solving - being able to arrive at an outcome or goal in the absence of a readily recognized pre-defined path or solution. In Tiruneh, Verburgh, and Elen (2014) skills and dispositions are differentiated.

The thorniness of this issue for educators, and its measurement, is evident from the above discussion and is aptly articulated in King et al. (1998):

The challenge of defining "thinking skills, reasoning, critical thought, and problem solving" has been referred to as a conceptual swamp in a study by Cuban (as cited in Lewis \& Smith, 1993, p. 1), and as a "century old problem" for which "there is no well-established taxonomy or typology" (Haladyna, 1997, p. 32). In addition, explanations of how learning occurs 
have been viewed as inadequate, with no single theory adequately explaining "how all learning takes place" (Crowl, Kaminsky, \& Podell, 1997, p. 23). (p. 7)

Of these elements of higher-order learning identified, critical thinking is the concept most often cited and researched (Saadé et al., 2012). Critical thinking according to Pascarella \& Terenzini (2005), as cited in Tiruneh, Vergurg, \& Elen (2014), refers to:

.... an individual's ability to do some or all of the following: identify central issues and assumptions in an argument, recognize important relationships, make correct inferences from data, deduce conclusions from information or data provided, interpret whether conclusions are warranted based on given data, evaluate evidence or authority, make self-corrections, and solve problems. (p. 2)

Meta-analyses in the area suggest that combining opportunity for dialogue, exposure to and practice with authentic inquiry-based, real-world and situated problems and examples, participation in open-ended discussions, and mentoring lead to enhanced generic critical thinking skills (Abrami et al., 2014; NC State University, 2014), while a meta-analysis conducted by Gellin (2003) found student involvement in Greek life, clubs and organizations, faculty and peer interactions, living on campus, and employment resulted in increased critical thinking.

There is a scant body of research work on problem-solving per se, especially in virtual learning environments, as opposed to problem-based learning for which there is ample research. Problemsolving, as an outcome or dependent variable, is not to be confused with problem-based learning, which is an input or independent variable. Problem-Based Learning, as stated before, is a teaching method that uses problems specifically designed to produce problem-solving skills, among other higher-order thinking skills. In other words, it is an input variable designed to produce the outcome variables. Research in this area focuses, for instance, on how a particular problem-based learning teaching method or strategy may impact on a student's perceptions or achievement or intentions (Alamro \& Schofield, 2012; Baturay \& Bay, 2010; Hsu, Hwang, Chuang, \& Chang, 2012; Oldenburg \& Hung, 2010), or how technology to support this teaching method affects these outcomes (Lan, Tsai, Yang, \& Hung, 2012; Land \& Green, 2000; Shen, Lee, \& Tsai, 2011; Stewart, MacIntyre, Galea, \& Steel, 2007; Taplin, 2000).

Problem-Solving skill, on the other hand, is the outcome that is achieved by any teaching method employed, which may or may not include problem-based learning, and research surrounding it may not necessarily examine the teaching method at all. When problem-solving as an outcome variable is examined, performance is often used as a surrogate measure. It is usually a measure of scores on exams or assignments and research results that are available have been contradictory. A meta-analysis of studies from 1995-2004 conducted by Jahng, Krug, \& Zhang (2007) found no differences in student achievement between online distance education and face-to-face, while Means, Toyama, Murphy, Bakia, \& Jones (2009), looking at studies from 1996-2008, found online delivery outperformed face-to-face delivery. In the studies examined by Sitzmann, Kraiger, Stewart, \& Wisher (2006), web-based learning was found to be $6 \%$ more effective in conveying declarative knowledge than the traditional classroom delivery; however, this disappeared if the same instructional method was applied in both delivery settings. There was no difference in conveying procedural knowledge nor in the satisfaction of students. Looking at achievement and attitude outcomes from 1105 studies, Schmid et al. (2014) found subject matter, degree of difficulty in technology use and pedagogical use of technology to be predictors of these outcomes. They also found that cognitive support tools produced better results than presentation support tools.

The potential for inconsistencies in meta-analysis research results, according to Bernard (2014) and Phipps \& Merisolis (1999), among other things, arises from questionable research quality due to lack of control of extraneous variables, non-randomization of subjects, questionable reliability 
and validity of instruments and lack of control of the feelings and attitudes of students and faculty, and various biases. Drawing definitive conclusions is therefore difficult. (See Morin et al., 2014, and Thomas, Morin, \& Ly, 2014, for a summary of various meta-analyses in the field, in the area of online and blended learning versus traditional learning, though not all are specifically concerned with problem-solving.)

According to the definition of decision-making given by Beachboard \& Aytes (2013), and supported by others (Johnson, Archibald, \& Tenenbaum, 2010; Pedaste, Pentjärv, \& Sarapuu 2003), when it comes to scholastic and professional performance, problem-solving is a key skill that individuals need in order to succeed, to achieve the requisite level of decision-making for the task.

Decision-making is directly associated with selecting one course of action among two or more possible alternatives. Decision-making is driven by a desire to solve problems or exploit opportunities. A problem refers to some type of event that requires a response to avoid a negative consequence. Conversely an opportunity is an event or situation where a response is required to make something desirable happen. (Beachboard \& Aytes, p. 16)

The Big Six information problem-solving process proposed by Eisenberg \& Berkowitz (1988) suggests that problem-solving requires defining the task and identifying the information needed to solve it, determining sources for the information, locating the sources and the information, extracting the information, synthesizing the information, and evaluating the information. It is regarded as one of the most important skills needed to be able to handle the novel, changing requirements of any job function, and in the current information age, how to bring technology to bear on this problem-solving (Hennessy, Mccormick, \& Murphy, 1993). As Eisenberg \& Johnson (1996) noted, this means going beyond the how of technology use, to the when and why, what they refer to as true computer literacy. That means:

...knowing the basic operations, terminology, and maintenance of equipment; knowing how to use computer-assisted instructional programs and other specialized, task-specific applications; having a knowledge of the impact of technology on careers, society, and culture; knowing computer programming. (p. 1)

The acquisition, understanding, and use of knowledge require various learning strategies, metacognitive skills and the desire to use them. In order to learn in the academic environment, as well as to perform well later in the workplace, students need the skills to acquire, absorb, and transfer knowledge efficiently and effectively (Eisenberg \& Berkowitz, 1988). This implies being able to apply problem-solving skills, associated research and creative idea generation skills, and critical thinking skills to situations as they arise.

From the above discussion, there is an evident need for students to develop problem-solving skills, and there is also evidence of support for the idea that problem-solving skills are undergirded by research skills, critical thinking skills, and creativity skills. Past research has focused mostly on differences in delivery methods rather than on an examination of the components of problem-solving, with its associated research, creative idea generation skills, and critical thinking skills, as is being proposed in the model presented here. As a general concept, higher-order thinking skills have been considered important skills to develop, critical thinking being the one most researched as noted previously (Saadé et al., 2012), but not in association with the other skills identified here and not as a supporting leg of problem-solving. The current research proposes that critical thinking should be considered as a supporting leg of problem-solving. There is potentially additional challenge in attempting to develop these skills in a virtual environment, without the usual face-to-face interaction where immediate feedback and assistance are available. There is little research in this area, hence the focus being given to it in this paper. 


\section{Methodology}

As the authors are not aware of other research that has looked into these ideas, the purpose of the research presented here was to investigate what observations could be made about students' perceptions of their acquisition of an important aspect of higher-order learning, namely, problemsolving, and the supporting research, critical thinking and creative idea generation skills, from the various activities, resources and technologies used in the course.

With this in mind, the following research questions were investigated:

1. To what extent do students understand the definitions of Problem-solving, Research skills, Creative Idea Generation skills, and Critical Thinking skills?

2. What is the relative contribution of the learning components (activities and resources) of the course to the perceived acquisition of Problem-solving, Research skills, Creative Idea Generation skills, and Critical Thinking skills?

3. Is the understanding of the definitions correlated with the perceived contributions of the learning components (activities and resources) of the course to the skills development?

4. To what extent is perceived Problem-solving skill acquisition explained by the acquisition of the other three skills?

In this paper, the following definitions are used (Thomas, 2001).

Problem-solving: deriving alternatives and solutions for complex problems/issues with incomplete information, this is built on:

(1) Research skills: investigating, finding, and synthesizing information from multiple sources;

(2) Creative idea generation: ideas that are novel or unique; and

(3) Critical thinking: analysis, inference, reasoning, evaluation, explanation, interpretation.

A questionnaire was devised and administered to determine how problem-solving skills were perceived in an online information technology course. In specific, students in an entirely virtual, online course were asked to provide a subjective assessment of the extent to which they felt various activities, resources, and technologies supported their acquisition of problem-solving skills and its supporting legs - research skills, critical thinking skills, and creative idea generation skills.

\section{The Procedure}

The course used in this study is "Fundamentals of Information Technology and Business Productivity" and is offered by the business school. The course includes the following subjects: Understanding computer parts; Making the most of Web resources; Application software; Operating systems; Utility programs; Hardware; Networking; Securing your computer and digital data; Microsoft Excel; and Microsoft Access. Microsoft Excel and Access constitute 50\% of the course and are task based using the SAM tool (http://sam.cengage.com). This task-based component of the course entails pre-assessment, training, and post-assessment of skills which are later strengthened by a problem-based mini case. Learning the IT knowledge areas (subjects) identified is done through an ebook, a set of videos and audio files, and EISEL (an interactive questioning tool). Students are assessed by quizzes and 2 exams. The first exam covers the first half of the book and the second covers the second half.

This course is offered to all students entering the business school who do not meet information technology admission requirements, that is, do not have the pre-requisite knowledge of information technology fundamentals. At the same time, many students from other faculties can take this course as an elective. Approximately, $50 \%$ of the students who take the course are from outside of the business school. The course is completely online with no face-to-face contact with the 
teaching assistant or the professor. There are, however, weekly office hours held by the teaching assistant of which only a few students take advantage (as experienced and noted in the last five years). Approximately 2700 students enroll in this course every year.

From an instructional design perspective, the course included practice quizzes, readings, proctored exams, video and audio, business problem-solving cases, Excel and Access simulations and assignments. In essence the course entailed many activities that require students to not only learn the content but also establish interconnections between them to specific context. Pedagogically speaking, the course is primarily based on the cognitivist approach. Ever since the 1950's, psychologists and educators have stressed the complex cognitive processing that occurs during the act of learning. Learning is equated with discrete changes between states of knowledge, and the acquisition of knowledge is described as a mental activity that entails internal coding and structuring by the learner (the learner is an active participant in the learning event). To that end, cognitive theories and cognitive-based activities are considered more appropriate for explaining complex forms of learning such as reasoning, critical thinking and problem-based learning.

In such a course, the fundamental premise to establish a cognitively supported online environment is the inclusion of many activities (independent or semi-independent) that students can engage with, and in doing so, allow the student to think of the interconnections. Students taking the course are required to demonstrate acquisition of basic IT knowledge and lower level skills, such as remembering concepts as well as keystrokes in software, and additionally, the mechanics of how to solve problems with the software being learnt. Learning in the course is supported by various activities and resources, as well as different technologies. There are three websites that students need to access for the course. Each website contains different tools. These tools manage the concepts and content via different media formats. For example, some interactive activities were assignments, an Excel project, an Access project, and quizzes, in addition to an educational information system for enhanced learning (EISEL). The resources were the textbook, the online book chapters, the overall online system, and the material on the web. Overall, students realize early in the course that they are active participants and equally responsible of their learning process.

Data was collected via an optional online survey at the end of the course, which was posted on the Moodle ${ }^{\mathrm{TM}}$ course management software platform. Students were instructed that there were no right or wrong answers and that interest was primarily in their beliefs and perceptions about the course components and their experiences with the different tools for learning. Students were asked to respond to the survey as candidly as possible.

\section{Instrument Description}

The survey was divided into three major parts. The first part contained open-ended demographic questions related to program of study (5 questions): gender, age, level of computer experience, and mother tongue. The second part was about the students' level of understanding of definitions. There were 4 questions evaluated from 0 - no understanding, to 10 - perfect understanding. The third part was about perceptions of the contributions of the various activities and resources of the course to problem-solving and its component skills. For each of the four skills, namely, Problemsolving, Research, Creativity, and Critical Thinking, students were asked to identify at what level each of the class activities and resources contributed to their perceived development of these skills on a 3-point scale, where 1 indicated - not at all, 2 - moderate, and 3 - a lot. There were 28 questions. 


\section{Instrument Development}

Building on prior research conducted by the authors, the survey used in this study measures the subjective evaluation of the students' use and/or development of problem-solving skills, research skills and creative idea generation skills, as well as critical thinking skills, while interacting with the course resources, activities and technologies (Thomas \& Morin, 2010). The survey used in this study is based on an instrument developed by the second author (Thomas, 2001). The reliability of the instrument as measured by the Cronbach Alpha is very solid, Problem-Solving 0.861, Research 0.879, Critical Thinking 0.907, and Creativity 0.861 .

These concepts of higher learning are consistent with those advocated by Chickering \& Gamson (1987) and Bloom \& Krathwohl (1956), and revisited in Anderson \& Krathwohl (2001), Dangel \& Wang (2008), ITS Education Asia (2014), Collins (2014), and Facione (2015). The authors are not aware of an instrument that examines problem-solving with its sub-components of research skills, critical thinking skills, and creative idea generation skills, as is being proposed here. Also, contrary to other instruments that usually measure the extent to which, or the reliability with which, questions are representative of a particular construct, the instrument in this research seeks students' perceptions of the support various activities, resources, and technologies used in a course contribute to their acquisition of the identified higher-order thinking skills. The purpose of this research is not to validate constructs but rather to seek perceptions about the constructs, hence instruments such as the California Critical Thinking Skills Test and others would not be appropriate (King et al., 1998, provide an extensive inventory of these instruments). As the extreme points of these perceptions were the focus of interest, a 3-point scale was adapted rather than the usual finer 5-point scale, which also often gets collapsed to a 3-point scale for purposes of analysis.

\section{Results}

To analyze the results, several statistical tools were used, such as descriptive statistics, correlation analysis, analysis of variance using Tukey-Kramer post-hoc tests, and multiple regressions to identify the factors that impact higher-order thinking skills acquisitions and potential differences in effectiveness.

\section{Demographics and Definition Understanding}

There were a total of 985 students enrolled in the course and 490 of them completed the survey online for a response rate of $51.2 \%$. Of those who completed the survey, $44 \%$ were female students. Most respondents (73.3\%) were in the $20-23$ age group, $17.4 \%$ in the $24-30$ age group and $4 \%$ and $5.3 \%$ were in the below 20 and above 30 categories, respectively. The average age is 22.7 years, while the median is 22 .

Research Question 1:

To what extent do students understand the definitions of Problem-solving, Research and Creative Idea Generation skills, and Critical Thinking skills?

Figure 2 shows the distribution of the scores representing students' self-reported level of understanding of the definition of the four skills used in the survey. A score of 0 indicates: 'Not at all' and a score of 10 indicates 'Perfect understanding'. The definitions are, as previously stated:

- Problem-solving: deriving alternatives and solutions for complex problems/issues with incomplete information

- Research: investigating, finding, and synthesizing information from multiple sources

- Creativity: ideas that are novel or unique

- Critical Thinking: analysis, inference, reasoning, evaluation, explanation, interpretation 


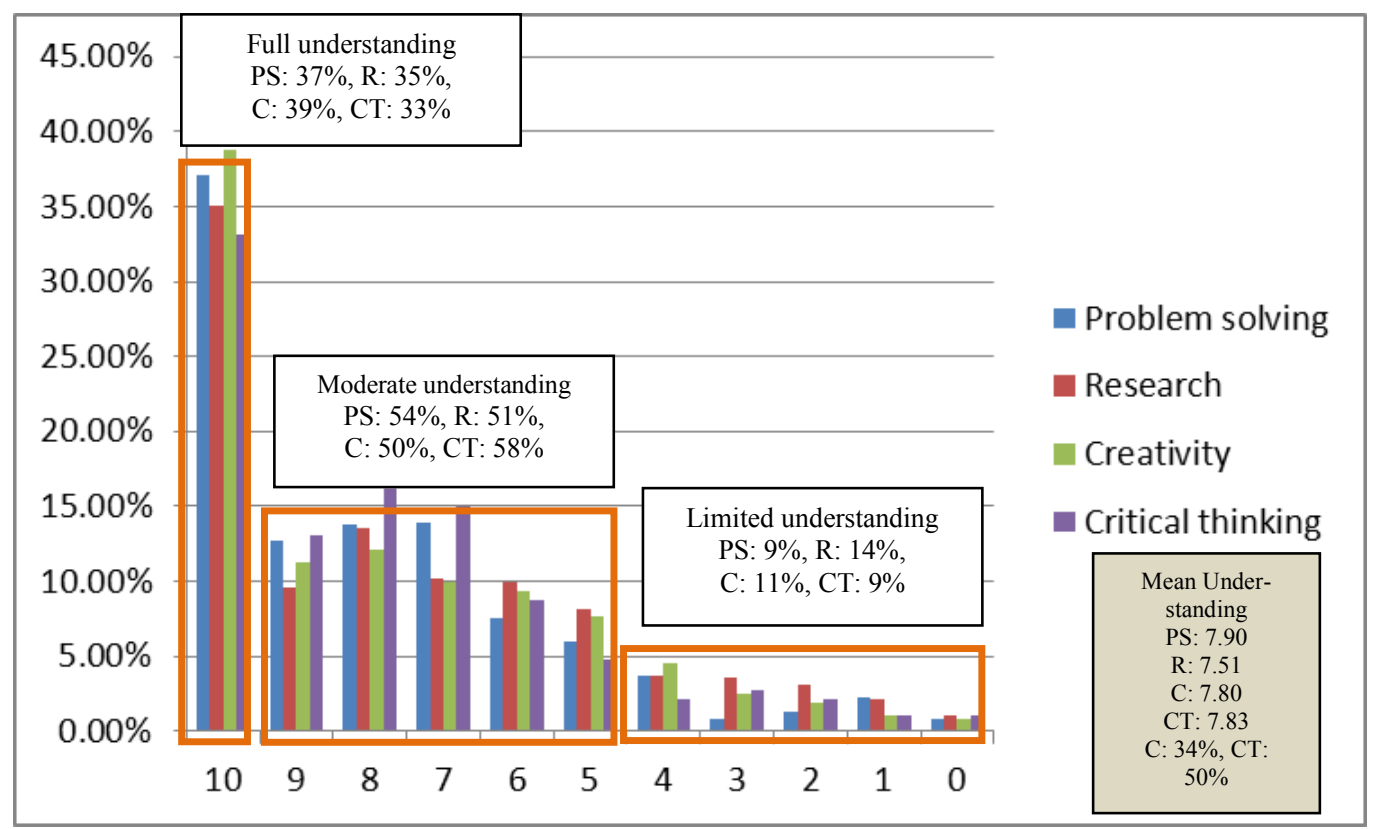

Figure 2. Understanding the Definitions from 0 to 10

The mean levels of understanding for the definitions of Problem Solving, Research, Creativity and Critical Thinking are 7.90, 7.51, 7.80 and 7.83 respectively. From the parallel bar chart, the levels of understanding can also intuitively be split into three categories as follows:

Full understanding for score of 10

Moderate understanding for scores from 5 to 9 and

Limited understanding for scores from 0 to 4 .

From Figure 2, it can also be observed that $91 \%, 89 \%, 91 \%$ and $86 \%$ of students have at least a moderate or better understanding of the definition of Problem-solving, Creativity, Critical Thinking and Research skills, respectively.

\section{Contribution of Activities and Resources}

Research Question 2:

What is the relative contribution of the various learning components (activities and resources) of the course to the perceived acquisition of Problem-Solving, Research, and Creative Idea Generations skills, and Critical Thinking skills?

Students were asked to assess how different activities and resources in the course have assisted them in the development of their Problem-solving skills, Research skills, Creativity skills, and Critical Thinking skills using the following classification: 'A lot' (3), 'Moderate' (2) and 'Not at all' (1). In tabulating the results, we used this coding and the averages of ranking of students are shown in Table 1.

These means provide us with a measure of the perceived relative influence of course elements (activities/resources) on the development of skills. The table also presents the positive impact of each activities / resources defined as the total proportion of answers in the categories 'Moderate' and 'A lot'. The last column gives the mean perceived contribution of each activity and resource to the combined set of skills: Research, Creativity and Critical thinking as well as the mean positive impact. We note that the results in this last column are never as high as those of the Problemsolving skill which is an indication that although they explain a good portion of Problem-solving skills acquisition, other skills should be identified in future research projects. 


\begin{tabular}{|l|c|c|c|c|c|c|}
\hline \multicolumn{6}{|c|}{ Table 1. Students' Perceived Contribution of Activities and Resources } \\
to the Components of Problem-Solving (PS) \\
\hline
\end{tabular}

Approximately 75\%, (365/490 - those who answered the questions about the textbook divided by the total sample size) of the students bought the physical textbook and, from the results in Table 2 , about $78.4 \%$ of them considered that it had a positive impact on the acquisition of Problemsolving skills. Similarly, the perceived contribution of the Online book chapters to Problemsolving was positive, though lower at $75 \%$. Moreover, it seems that students felt that most activities contributed more to skills improvement than did resources. In terms of the strongest positive impact, Assignments, Excel project and Access project generally are perceived as having contributed the most to skills development. On the other hand, and not surprisingly, the Quiz, the Textbook, the Online book chapters, and EISEL were perceived to contribute the least to the development of creativity skills.

The last row of Table 1 includes the significance of tests for equality of mean perceived contribution of activities and resources to the skill. Given the very large sample size utilized, averages that do not seem very different are in fact highly significantly different. Table 2 identifies the significant differences in perceived contributions to each skill by pairs of activities and resources using 
the Tukey-Kramer post hoc test. To avoid repetition, only the results under the diagonal are presented.

When a skill is found in a cell of Table 2, it means that the corresponding pair of activities, or corresponding pair of resources or pair of activity/resource has shown a statistically significant mean contribution to that skill. The '+' or '-' superscripts are used to indicate the direction of the significance. A '-' superscript indicates that the activity or resource in the first column contributes less than the activity/ resource on the first row. For example in the cell corresponding Assignment and Material on the Web, $\mathrm{PS}^{-}$is reported, which indicates that the mean perceived contribution of Assignment and Material on the Web to Problem Solving are significantly different, at 5\%, and more precisely, Material on the Web contributes less than the Assignments to Problem-Solving.

Table 2. Significant mean differences in students' perceived contribution of Activities and Resources to Problem-Solving (PS), Research (R), Creativity (C) and Critical Thinking (CT) using Tukey-Kramer Test at $5 \%$ level of significance

\begin{tabular}{|c|c|c|c|c|c|c|c|c|c|c|}
\hline & \multicolumn{5}{|c|}{ Activities } & \multicolumn{4}{|c|}{ Resources } \\
\hline & & Assign & Excel & Access & Quiz & EISEL & $\begin{array}{l}\text { Text } \\
\text { Book }\end{array}$ & $\begin{array}{c}\text { Online } \\
\text { Book }\end{array}$ & $\begin{array}{l}\text { Overall } \\
\text { online }\end{array}$ & $\begin{array}{l}\text { Material } \\
\text { on Web }\end{array}$ \\
\hline \multirow{5}{*}{ 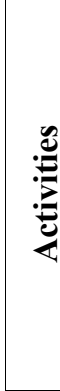 } & Assign & & & & & & & & & \\
\hline & Excel & & & & & & & & & \\
\hline & Access & & & & & & & & & \\
\hline & Quiz & $\mathrm{PS}^{-}, \mathrm{C}^{-}$ & $\mathrm{PS}^{-}, \mathrm{C}^{-}$ & $\mathrm{PS}^{-}, \mathrm{C}^{-}$ & & & & & & \\
\hline & EISEL & $\begin{array}{l}\mathrm{PS}^{-}, \mathrm{R}^{-}, \\
\mathrm{C}^{-}\end{array}$ & $\begin{array}{l}\mathrm{PS}^{-}, \mathrm{R}, \\
\mathrm{C}^{-}\end{array}$ & $\mathrm{C}^{-}$ & & & & & & \\
\hline \multirow{4}{*}{ 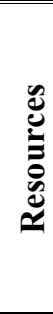 } & Textbook & $\begin{array}{l}\mathrm{PS}^{-}, \mathrm{R}^{-}, \\
\mathrm{C}^{-} \mathrm{CT}^{-}\end{array}$ & $\begin{array}{l}\mathrm{PS}^{-}, \mathrm{R}^{-}, \\
\mathrm{C}^{-} \mathrm{CT}^{-}\end{array}$ & $\begin{array}{l}\mathrm{PS}^{-}, \mathrm{R}^{-}, \\
\mathrm{C}^{-}, \mathrm{CT}^{-}\end{array}$ & $\begin{array}{l}\mathrm{R}^{-}, \\
\mathrm{CT}^{-}\end{array}$ & $\begin{array}{l}\mathrm{PS}^{-}, \\
\mathrm{CT}^{-}\end{array}$ & & & & \\
\hline & $\begin{array}{l}\text { Online } \\
\text { Book }\end{array}$ & $\begin{array}{l}\mathrm{PS}^{-}, \mathrm{R}^{-}, \\
\mathrm{C}^{-}, \mathrm{CT}^{-}\end{array}$ & $\begin{array}{l}\mathrm{PS}^{-}, \mathrm{R}^{-}, \\
\mathrm{C}^{-}, \mathrm{CT}^{-}\end{array}$ & $\begin{array}{l}\mathrm{PS}^{-}, \mathrm{R}^{-}, \\
\mathrm{C}^{-}, \mathrm{CT}^{-}\end{array}$ & $\begin{array}{r}\mathrm{PS}^{-}, \\
\mathrm{R}^{-} \mathrm{CT}\end{array}$ & $\begin{array}{l}\mathrm{PS}^{-}, \\
\mathrm{CT}^{-}\end{array}$ & & & & \\
\hline & $\begin{array}{l}\text { Overall } \\
\text { Online }\end{array}$ & $\begin{array}{c}\mathrm{PS}^{-}, \mathrm{R}^{-}, \\
\mathrm{C}^{-}\end{array}$ & $\begin{array}{l}\mathrm{PS}^{-}, \mathrm{C}^{-} \text {, } \\
\mathrm{CT}^{-}\end{array}$ & $\mathrm{PS}^{-}, \mathrm{C}^{-}$ & & $\mathrm{C}^{+}$ & & $\begin{array}{l}\mathrm{PS}^{+}, \\
\mathrm{R}^{+},\end{array}$ & & \\
\hline & $\begin{array}{l}\text { Material } \\
\text { Web }\end{array}$ & $\mathrm{PS}^{-}$ & $\begin{array}{l}\mathrm{PS}^{-}, \mathrm{C}^{-}, \\
\mathrm{CT}^{-}\end{array}$ & $\begin{array}{c}\mathrm{PS}^{-}, \mathrm{C}^{-}, \\
\mathrm{CT}^{-}\end{array}$ & $\mathrm{C}^{+}$ & $\mathrm{C}^{+}$ & $\begin{array}{l}\mathrm{R}^{+}, \\
\mathrm{CT}^{+}\end{array}$ & $\begin{array}{r}\mathrm{R}^{+}, \mathrm{C}^{+}, \\
\mathrm{CT}^{+}\end{array}$ & & \\
\hline
\end{tabular}

From Table 2, the following observations can be made concerning the four skills:

\section{Problem-Solving}

Examining pairs of Activities, Assignments, Excel and Access all produced significantly higher perceived differences in Problem-Solving skill acquisition than the Quizzes, while Assignments and Excel were also greater than EISEL.

$$
\begin{aligned}
& \checkmark \text { (Assign, Excel, Access>Quiz), } \\
& \checkmark \text { (Assign, Excel>EISEL), }
\end{aligned}
$$

Examining pairs of Resources, Overall Online had a greater impact on this skill than did the Online Book Chapters.

\section{$\checkmark \quad$ (Online Book Chapters $<$ Overall Online)}


Examining pairs of Activity / Resource, Assignments, Excel, Access and EISEL had a greater impact than the Textbook or the Online Book Chapters. The Quiz also had a greater impact than the Online Book Chapters. The Assignments, Excel and Access were perceived as having a greater effect on problem-solving than did the Overall Online or the Material on the Web.

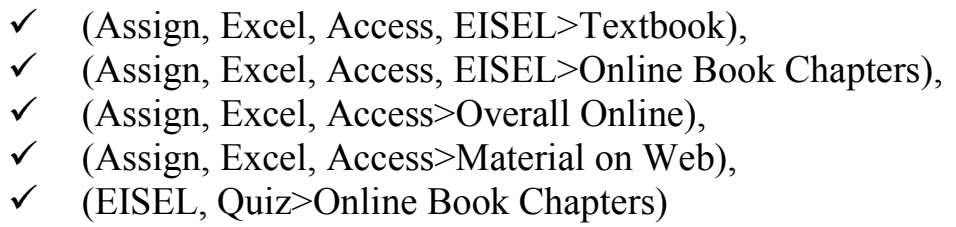

\section{Research}

Examining pairs of Activities, both Assignments and Excel were perceived as contributing more to the development of Research skills than EISEL.

$\checkmark$ (Assign, Excel>EISEL),

Examining pairs of Resources, Material on the Web was perceived more favorably in developing this skill than either the Textbook or the Online Book Chapters. The latter was less favored than the Overall Online.
$\checkmark$ (Online Book Chapters, Textbook $<$ Material on the Web),
$\checkmark$ (Online Book Chapters $<$ Overall Online)

Examining pairs of Activity / Resource, Assignments, Excel, Access and the Quizzes all were perceived more positively in developing Research skills than the Textbook and the Online Book Chapters. The Assignments were also favored over the Overall Online.

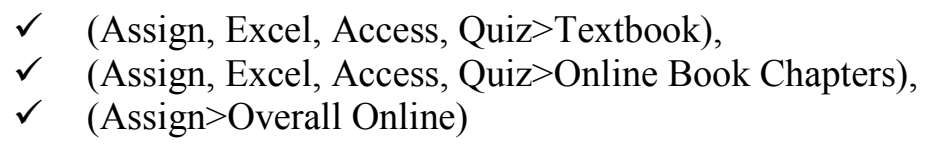

\section{Creativity}

Examining pairs of Activities, Creativity was deemed as being significantly better supported by Assignments, Excel and Access than by the Quizzes or EISEL,

$$
\begin{array}{ll}
\checkmark & \text { (Assign, Excel, Access>Quiz), } \\
\checkmark & \text { (Assign, Excel, Access> EISEL), }
\end{array}
$$

Examining pairs of Resources, Material on the Web more supportive than the Online Book Chapters.

\section{$\checkmark \quad$ (Online Book Chapters $<$ Material on Web)}

Examining pairs of Activity / Resource, the Assignments, Excel and Access were perceived to contribute more to this skill development than the Textbook, the Online Book Chapters or the Overall Online. EISEL was considered to contribute less than the Overall Online or the Material on the Web, while Excel, Access and the Quiz were considered to contribute more than Material on the Web.

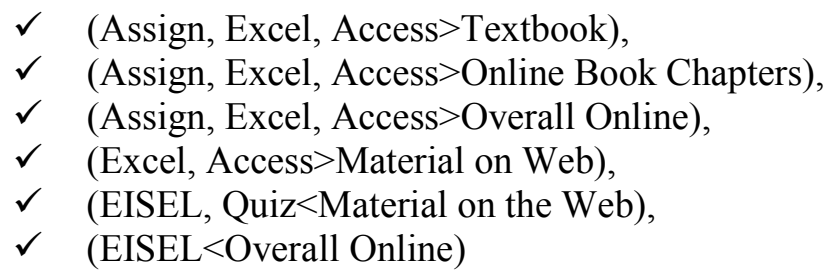




\title{
Critical Thinking
}

Examining pairs of Activities, it was found that no activities were perceived to contribute differently to critical thinking skills development.

Examining pairs of Resources, Material on the Web was perceived as contributing more to the development of critical thinking than the textbook, and the online book chapters contributed less than the Material on the Web or Online Overall.

$\checkmark$ (Textbook, Online Book Chapters $<$ Material on the Web),

$\checkmark$ (Online Book Chapters $<$ Online Overall)

Examining pairs of Activity / Resource, Assignments, Excel, Access, the Quizzes, and EISEL were all perceived to provide better support than the Textbook or Online Book Chapters to the development of critical thinking. Excel and Access additionally were perceived to be more supportive than Material on the Web. Excel was also more supportive than Overall Online.

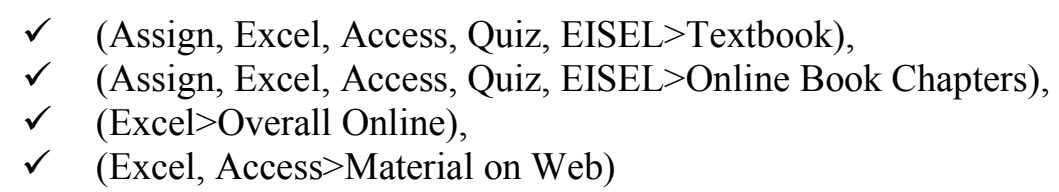

From Table 2, the following observations can also be made concerning the Activities, Resources and Activities/Resources:

\section{Activities}

Assignments and Excel provided better support than EISEL of all the skills except for Critical Thinking, for which no differences were found. They were also better than Quiz for ProblemSolving and Creativity. Access was better than the Quiz for Problem-Solving and Creativity and also better than EISEL for Creativity.

\author{
Problem-Solving - Activities \\ $\checkmark$ (Assign, Excel, Access $>$ Quiz), \\ $\checkmark$ (Assign, Excel $>$ EISEL), \\ Research - Activities \\ $\checkmark$ (Assign, Excel $>$ EISEL),

\section{Creativity - Activities} \\ $\checkmark$ (Assign, Excel, Access $>$ Quiz), \\ $\checkmark$ (Assign, Excel, Access $>$ EISEL), \\ Critical Thinking - Activities \\ $\checkmark$ none contributed
}

\section{Resources}

The Overall Online System provided better support than Online Book Chapters for all skills, except for Creativity. Material on the Web provided better support than the Online Book Chapters and the Textbook for Research and Critical Thinking and also better than the Online Book Chapter for Creativity.

\section{Problem-Solving - Resources}

$\checkmark$ (Online Book Chapters $<$ Overall Online), 


\author{
Research - Resources \\ $\checkmark$ (Online Book Chapters, Textbook $<$ Material on the Web), \\ $\checkmark$ (Online Book Chapters $<$ Overall Online)

\section{Creativity - Resources} \\ $\checkmark$ (Online Book Chapters $<$ Material on the Web),

\section{Critical Thinking - Resources} \\ $\checkmark$ (Textbook, Online Book Chapters $<$ Material on the Web), \\ $\checkmark$ (Online Book Chapters $<$ Online Overall)
}

\title{
Activities/Resources
}

Assignments, Excel and Access provided better support than the Textbook and Online Book Chapters for all the skills. EISEL and Quiz were also better than Online Book Chapters for Problem-Solving and Critical Thinking. Excel is better than Overall Online System and Material on the Web, except Research. This is the same result for Access compared to Material on the Web. Assignments and Access are better than Overall Online System for Problem-Solving and Creativity, while Assignments is also better for Research. Quiz is better than Textbook and Online Book Chapters for Critical Thinking and Research. Material on the Web and Overall Online System are better than EISEL for Creativity, and Material on the Web is also better than the Quiz for Creativity but Assignments are better than Material on the Web for Problem-Solving.

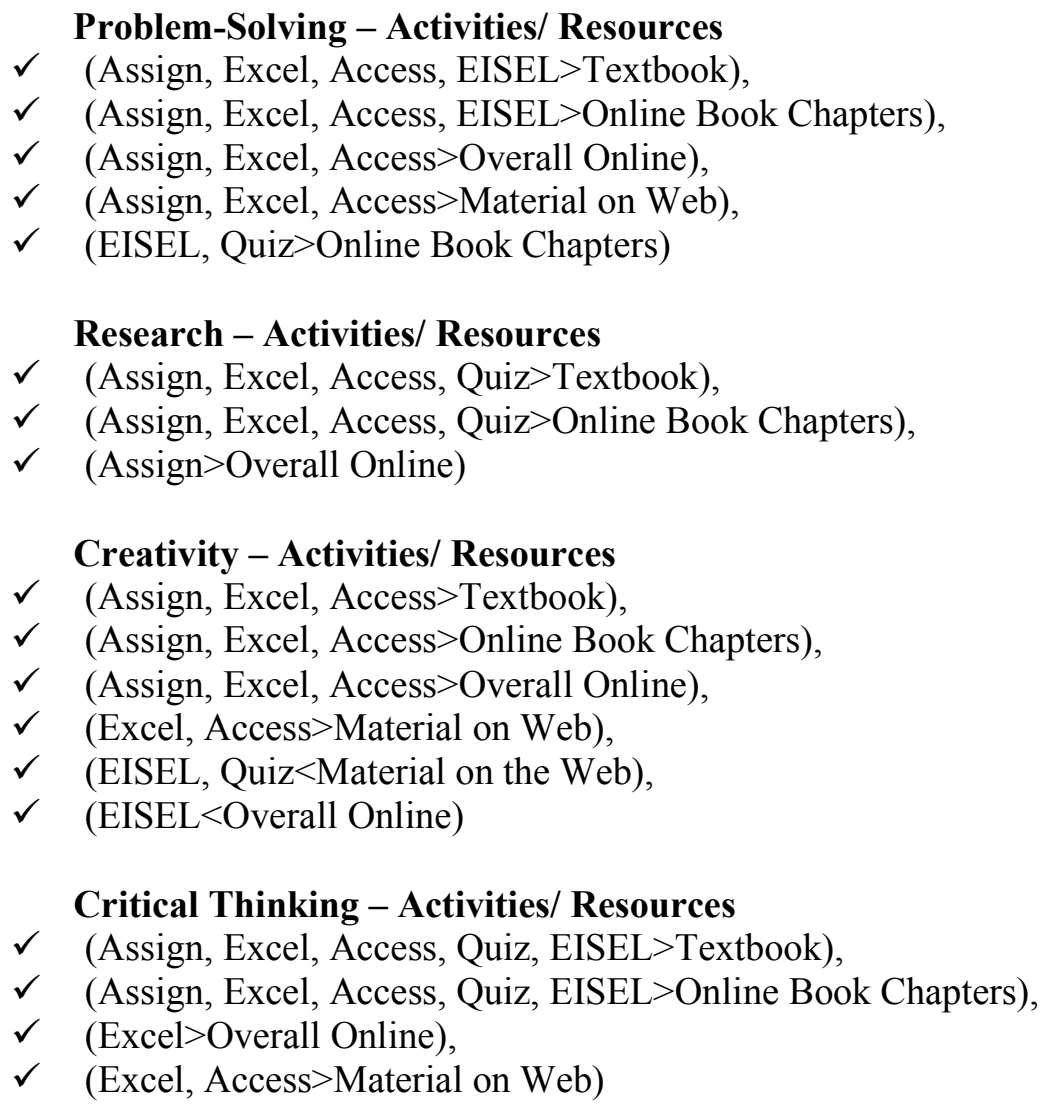

These comparisons have implications for the design of web-based learning content. 


\section{Perceptions and Understanding of the Definitions of Components of Problem-Solving}

Research Question 3:

Is the understanding of the definitions correlated with the perceived contributions of the learning components (activities and resources) of the course to the skills development?

As it is unknown whether the understanding of the definitions could be correlated to the students' perceived acquisition of problem-solving skills and its components, the definitions of which may not be uniformly understood, a correlation analysis is presented in Table 3. Researchers often use these terms interchangeably so some correlation could be expected.

We note that most correlations are not significantly different from 0 at the $5 \%$ level, except in the cases of problem-solving and creativity. The perceived contributions of the Assignments and Access project to problem-solving seem to increase with the understanding of the definition.

\begin{tabular}{|c|c|c|c|c|}
\hline \multicolumn{5}{|c|}{$\begin{array}{r}\text { Table 3. Correlations Between Understanding of Skills Defin } \\
\text { Contribution of Activities/ Resources to tha } \\
\text { Understanding of definitions of skills }\end{array}$} \\
\hline 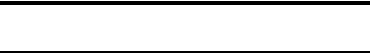 & Problem-solving & Research & Creativity & Critical Thinking \\
\hline \multicolumn{5}{|l|}{ Activities } \\
\hline Assignments & $0.135^{*}$ & 0.074 & -0.037 & 0.020 \\
\hline Excel project & 0.075 & 0.036 & 0.005 & 0.053 \\
\hline Access project & $0.094 *$ & 0.080 & -0.031 & 0.058 \\
\hline Quiz & 0.047 & 0.050 & $-0.090^{*}$ & 0.042 \\
\hline EISEL & -0.012 & 0.003 & $-0.107 *$ & 0.034 \\
\hline \multicolumn{5}{|l|}{ Resources } \\
\hline Textbook & -0.048 & 0.028 & -0.077 & -0.088 \\
\hline Online Book Chapters & 0.015 & 0.287 & -0.076 & 0.010 \\
\hline Overall Online System & 0.060 & 0.053 & -0.025 & 0.046 \\
\hline Web Material & 0.009 & 0.090 & -0.026 & -0.023 \\
\hline
\end{tabular}

On the other hand, the perceived contributions of the quizzes and of EISEL to creativity seem to decrease with the understanding of the definition of creativity. As students' understanding of the definition of Creativity increases, their perceptions of the contribution of Quizzes and EISEL decrease. Although these correlations are significant, they are weak in value, they are suggestive of some associations, but should be used with cautious.

\section{Relationship of Research, Creativity and Critical Thinking to Problem-Solving}

Research Question 4:

To what extent is perceived Problem-solving skill acquisition explained by the acquisition of the other three skills?

In this research, we also hypothesize that the Problem-solving skill will be partially explained by three other skills, namely, Research, Creativity and Critical Thinking. As noted previously from Table 1, the results combining these three skills are never as high as those of the Problem-solving 
skill which is an indication that although they explain a good portion of Problem-solving skills acquisition, they don't explain all of it. This is supported by Table 4 where multiple regressions show that the variation in the perceived contribution to Problem-solving skills is strongly explained by the regression on the three other perceived contributions. The variables in Table 4 are presented using the following notation: ASS_PS corresponds to the perceived contribution of the Assignments to Problem-Solving, etc.

\begin{tabular}{|l|l|c|c|c|c|}
\hline \multicolumn{1}{|l|}{ Table 4. Regression models to Predict the Perceived Contribution to Problem-Solving (PS) } \\
Skill using the perceived contribution to Research (R), Creativity (C) and Critical Thinking \\
(CT) skills as predictors for each Activity and Resource
\end{tabular}

We note that all multiple regressions are highly significant with p-values lower than 0.000001 , which means that perceived contributions of activities and resources to Problem-solving skills are partially explained by their contribution to Research, Creativity, and Critical Thinking. Also all regression coefficients in each of the nine multiple regressions are highly significant as indicated by the t-ratios corresponding to each predictor. The most significant predictor for each regression is identified as the predictor with the smallest p-value corresponding to the largest t-ratio in absolute value. Therefore, Problem-solving stands on three legs: Research, Creativity, and Critical Thinking, as had been hypothesized; however, the coefficients of determination indicate that they do not tell all the story, other factors are also at play and need further research. For example, in 
the first regression in Table 4, the coefficient of determination is $40.09 \%$, which means that the variation in the perceived contribution of Assignments to Problem-Solving is explained by the perceived contribution of Assignments to Research, Creativity, and Critical Thinking

Focusing in on the impact of the activities and resources on problem-solving, we obtain that $55.76 \%$ of the variation in the perceived contribution of the Excel project to Problem-solving skills is explained by the contribution of the Excel project to Research, Creativity, and Critical Thinking, where Research is the most significant predictor. Similarly $54.2 \%$ of the variation in the perceived contribution of the ACCESS project to Problem-solving skills is explained by the contribution of the three skills and Critical Thinking and Research are the most equally important predictors.

The perceived contributions to Problem-solving skills of the other activities: Assignments, Quiz and EISEL are also partially explained $(40.48 \%, 50.47 \%$ and $44.36 \%$ respectively) by their perceived contributions to the three skills, where Research and Critical thinking are, respectively, the most significant predictors.

As for the resources in the course, we note that the perceived contribution of the Web material to Problem-solving is explained more $(63.67 \%)$ by its perceived contributions to the other three skills than by the perceived contribution of any other resources $(43.34 \%, 43.24 \% 54.57 \%$ and $44.36 \%$ ) and even activities. The most significant predictor is Research, which could be explained by the fact that students have to search the course content and distinguish between important and less important elements of the course. Similar results are found for the Online book chapters but to a lesser extent when we consider its coefficient of determination, 43.24\%. For the Textbook and the Overall online system, Creativity is the most significant predictor, while for EISEL, Critical Thinking is most significant.

The above multiple regressions of Table 4 support the hypothesis that Problem-Solving stands on the three legs of Research, Creativity and Critical Thinking.

\section{Discussion}

Results of the study indicate that the definitions of the skills employed, which were based on the literature, are reasonable. (Beachboard \& Aytes, 2013; Brookhart, 2010; Collins, 2014; Eisenberg \& Berkowitz, 1988; King et al., 1998; Lewis \& Smith, 1993; Pascarella \& Terenzini, 2005; Tiruneh et al., 2014). Students had a very good understanding of the definition of the skills as articulated. Level of understanding varied across the skills and in general among students, but more than $85 \%$ of students had at least a moderate or better understanding while less than $15 \%$ had limited understanding of the terms. Research skills, with an average understanding of 7.5 , was the least understood, however, this could be due to the fact that this is a group of mainly first year undergraduate students, with limited research exposure.

Certain activities and resources were perceived to contribute more than others, which were the Assignments and the Excel and Access projects. This supported prior findings (Morin et al., 2012). The Quiz, the Textbook, the Online book chapters, and EISEL, were perceived to contribute the least to the development of creativity skills. This is not surprising since these are practice tools and not primarily tools that develop creativity. The relationship is very small but significant, which again must be treated cautiously. It also seems from the regression analysis that the perceived contribution of the Activities to Problem-Solving skills is largely explained by Research and Critical Thinking skills, while for Resources it is Research and Creativity.

As the understanding of the definition of Problem-Solving increases, the perceived contribution to this skill, of the Assignment and Access project also increase. On the other hand, as the definition of Creativity increases, the perceived contribution of the Quiz and EISEL decreases. The fact 
that students' perceptions increased with understanding of some constructs, suggests that students do not always know what they are learning, and that, when they do, they appreciate it more. Understanding and learning begets more understanding and learning, however, since those correlations are weak though significant, the results must be treated with caution but are still indicative of the direction.

The perceived contribution of an activity or a resource to Problem-Solving can be decomposed into three parts, which are the perceived contribution to Research, to Creative Idea Generation, and to Critical Thinking. The regression analyses, therefore, supported the hypothesis that Research, Creative Idea Generation and Critical Thinking are strong supporting legs of ProblemSolving, but did not tell the full story. Other factors are involved and need further investigation and elaboration. Some possibilities may include analytical, logical, reflective, metacognitive, decision-making and time management skills.

In the case of Assignments, Excel and Access, Online Book Chapters and Material on the Web, the perceived contribution to Research Skills was the strongest leg of the tripod, the most significant predictor of perceived Problem-Solving skills, while for Access, Critical Thinking is equally important. The findings could be explained by the fact that, as these activities and resources can be considered project-based, students have to search the course content and distinguish between important and less important elements of the course in order to apply them to the particular tasks at hand.

For Quizzes and EISEL, which are practice, learning tools, the most significant predictor of perceived Problem-Solving skills is the perceived contribution to Critical Thinking skills, which makes it the strongest leg of the tripod, which is in line with prior studies. The fact that students have to actively engage in using these tools to acquire and demonstrate their learning may explain their increased perception of contribution to critical thinking. When it comes to the Textbook and the Overall Online System, the strongest leg of the tripod is the perceived contribution to Creativity skills, which was the most significant predictor of perceived Problem-Solving skills. No ready explanation of this finding presents itself at this point.

These results of the study have implications for the design of web-based delivery of learning content. Understanding those aspects of a course that can contribute to developing problem-solving skills, and the other supporting skills - research, creativity, and critical thinking - can assist in this process and need further study. It is interesting that Research and Critical Thinking are grouped, as are Problem-solving and Creativity. Also, the fact that there are differences in the perceived contribution of the various activities and resources to the acquisition of higher-order skills has implications for the design of the content for web-based learning.

In summary, the following recommendations emerged:

The Assignments, Excel and Access were perceived to be more supportive of the development of all the thinking skills than either the Textbook or the Online Book Chapters.

$>$ Examining those supportive of three skills, the Assignments and Excel were more supportive than EISEL or Overall Online for developing Problem-Solving, Research, and Creativity while Excel and Access were more supportive than Material on the Web in developing ProblemSolving, Creativity, and Critical Thinking. Excel was also more supportive than Overall Online in developing these skills. The Quizzes were more supportive of Problem-Solving, Research, and Critical Thinking than the Online Book Chapters, which were themselves more supportive than the Overall Online. In developing Research skills, Critical Thinking, and Creativity, the Online Book Chapters were perceived to be more supportive than Material on the Web. Other pairs of activities/resources showed significantly different support of either one or two skills. 
Assignments, Excel, Access showed significant differences in developing Problem-Solving and Creativity over Quizzes, EISEL, Textbook, Online Book Chapters, Overall Online, and Material on the Web.

$>$ Assignments, Excel, and Access were more supportive of Research and Critical Thinking than the Textbook and Online Book Chapters, and Online Book Chapters more supportive than Overall Online and Material on the Web. The Textbook was also more supportive than Material on the Web. The Assignment and Excel were more supportive of Research than EISEL, and Assignments also more supportive than Overall Online, while Excel and Access were more supportive of Critical Thinking than Material on the Web, and Excel more supportive than Overall Online.

$>$ Quizzes and EISEL were perceived as more supportive of Critical Thinking than the Textbook or Online Book Chapters, as was the Textbook and Online Book Chapters over Material on the Web. The Online Book Chapters were also more supportive of this skill than Overall Online. EISEL was more supportive of Problem-Solving than the Textbook and the Quizzes than the Online Book Chapters, while the Online Book Chapters were more supportive than Overall Online. The Quizzes, EISEL and the Online Book Chapters were more supportive of Creativity than Material on the Web, and the EISEL was also more supportive than Overall Online.

The overall results point to the importance of incorporating assignments and Excel and Access projects in the development of the higher-order skills in Information Technology courses. Other activities and resources support the student in accomplishing these tasks but play a lesser role in developing these skills. As there is a tendency in online learning to put emphasis on rote memorization and true and false type questions for imparting and measuring learning, these results suggest more effort needs to be made to integrate more robust problem-solving tasks, even in an online context.

\section{Conclusion}

The body or research work related to higher order thinking skills and online learning is scarce. Research on critical thinking, problem-based learning, and creativity and research skills is extensive; however, few address them in the context on online learning. Of significant importance, a handful of researchers were found who explored the concepts of critical thinking and problembased learning in web environments. In problem-based learning four researchers began to experiment with wikis and forums, unguided group research, multimedia, web 2.0 tools, and the use of second life (Beaumont, Savin-Baden, Conradi, \& Poulton, 2014; Ioannou, Brown, \& Artino, 2015; Liu et al., 2014; Walker, 2014). In critical thinking, five recent articles were found where researchers explored web-based seminars, web 20 tools and mobile learning in nurse's education, web-based graduate management courses, and wikis (Condon \& Valverde, 2014; Eales-Reynolds, Gillham, Grech, Clarke, \& Cornell, 2012; Garcia \& Hooper, Jr., 2011; Goh, 2012; Lai \& Wu, 2012). It is evident that problem-based learning in online (or web-based) environment is the most recent subject to be addressed and interest in general seems to be increasing. It must be stressed, though, that these recent works in critical thinking and problem-based learning in online environments are primarily descriptive and addressed issues such as practices and strategies with little analytics/statistics. Moreover, most of these studies were in context different than higher education, such as nurse training, teacher education, elementary school students, and pre-service teachers.

The authors are not aware of other studies which have looked at the elements of this research in quite the way presented in this study and the results found suggest the need for further study and elaboration of these ideas. Possible expansions of this study include looking at the effect of teambuilding skills on the elements of problem solution, which is the topic of a subsequent paper, as well as expanding the types and number of questions used in the survey. In a recent study (Tsai \& 
Chiang, 2013) where a review of research in problem-based learning in online education environment was performed, the authors report on the number of publications per target student groups. What is interesting is that over the 8 year period 63 articles were published, giving an average of 8 articles per year. If only higher education students are considered, the number of publications falls by around $25 \%$. Needless to say, research in online education and problembased learning is scarce, even more so if one considers problem-solving skills acquisition in particular. Conducting a small research on Google Scholar on higher-order thinking and eLearning resulted in less than 10 articles over the past 5 years.

It is clear that the study of various higher-order thinking skills in eLearning environments (online education) is scarce; therefore, any insights that can be used to further our understanding via comparative synthesis are rare and therefore make our task the more difficult. However, in a study performed by Fox \& Mackeogh (2003) on eLearning's ability to promote higher-order learning via different pedagogical methods, it was suggested that given the appropriate pedagogical design, students can develop effective ways of engaging with the online course activities showing evidence of engaging in higher-order learning. This is in-line with the present study findings, as well as prior research by the authors (Morin et al., 2014; Saadé et al., 2012; Thomas \& Morin, 2010), and supports the results that pedagogically sound online activities can engage students in higher-order learning. As one would expect, (Schmid, et al., 2014), pedagogy is more important than the medium of delivery. The fact that these research results indicate that ProblemSolving is supported by the tripod idea of Research, Creative Idea Generation, and Critical Thinking opens another avenue for research into effective online pedagogy.

\section{References}

Abrami, P. C., Bernard, R. M., Borokhovski, E., Waddington, D. I., Wade, C. A., \& Persson, T. (2014). Strategies for teaching students to think critically: A meta-analysis. Review of Educational Research, September 25, 1-40.

Alamro, A. S., \& Schofield, S. (2012). Supporting traditional PBL with online discussion forums: A study from Qassim Medical School. Medical Teacher, 34, S20-S24.

Anderson, L. W., \& Krathwohl, D. R. (Eds.). (2001). A taxonomy for learning, teaching and assessing: A revision of Bloom's taxonomy of educational objectives: Complete edition. New York: Longman.

Baturay, M. H., \& Bay, O. F. (2010). The effects of problem-based learning on the classroom community perceptions and achievement of web-based education students. Computers \& Education, 55, 43-52.

Beachboard, J., \& Aytes, K. (2013). An introduction to business problem-solving and decision-making. Proceedings of Informing Science \& IT Education Conference (InSITE), Porto, Portugal, July.

Beaumont, C., Savin-Baden, M., Conradi, E., \& Poulton, T. (2014). Evaluating a Second Life ProblemBased Learning (PBL) demonstrator project: What can we learn? Interactive Learning Environments, 22(1), 125-141.

Bernard, R.M. (2014). Things I have learned about meta-analysis since 1990: Reducing bias in search of "the big picture". Canadian Journal of Learning and Technology, 40(3), 2-17.

Bloom, B. S., \&. Krathwohl, D. R. (1956). Taxonomy of educational objectives: The classification of educational goals, by a committee of college and university examiners. Handbook 1: Cognitive domain. New York: Longmans.

Brookhart, S. (2010). How to assess higher order thinking skills in your classroom, ASCD. Retrieved from http://www.ascd.org/Publications/Books/Overview/How-to-Assess-Higher-Order-Thinking-Skills-inYour-Classroom.aspx

Chickering, A. W. \& Gamson, Z. (1987). Seven principles for good practice in undergraduate education. American Association for Higher Education Bulletin, 39(7), 3-7. 
Collins, R. (2014). Skills for the $21^{\text {st }}$ Century: teaching higher-order thinking. Curriculum and Leadership Journal, 12(14).

Condon, C., \& Valverde, R. (2014). Increasing critical thinking in web-based graduate management courses. Journal of Information Technology Education: Research, 13, 177-191. Retrieved from http://www.jite.org/documents/Vol13/JITEv13ResearchP177-191Condon0354.pdf

Dangel, H. L., \& Wang, C. X. (2008). Student response systems in higher education: Moving beyond linear teaching and surface learning. Journal of Educational Technology Development and Exchange, 1(1), 93-104.

Davis, F. D. (1989). Perceived usefulness, perceived ease of use, and user acceptance in information technology. MIS Quarterly, 13(3), 319-340.

Eales-Reynolds, L. J., Gillham, D., Grech, C., Clarke, C., \& Cornell, J. (2012). A study of the development of critical thinking skills using an innovative web 2.0 tool. Nurse Education Today, 32(7), 752-756.

Eisenberg, M., \& Berkowitz, R. (1988). Library and information skills curriculum scope and sequence: The big 6 skills. School Library Media Activities Monthly, 5(1), 26-28, 45, 50-51.

Eisenberg, M., \& Johnson D. (1996). Computer skills for information problem solving: Learning and teaching technology in context. In ERIC Digest (ED: IR 055809 pending). Syracuse, NY: ERIC Clearinghouse on Information \& Technology March 1996. Available at http://eric.ed.gov/?id=ED392463

Facione, P. A. (2015). Critical thinking: What it is and why it counts. Retrieved December 1, 2015, from http://www.insightassessment.com/CT-Resources/Teaching-For-and-About-Critical-Thinking/CriticalThinking-What-It-Is-and-Why-It-Counts/Critical-Thinking-What-It-Is-and-Why-It-Counts-PDF

Fox, S., \& Mackeogh, K. (2003). Can eLearning promote higher-order learning without tutor overload? Open Learning, 18(2), 121-134.

Garcia, C. G. \& Hooper, Jr., H. H. (2011). Exploring factors of a web-based seminar that influence Hispanic preservice teachers' critical thinking and problem-solving skills. Journal of Hispanic Higher Education, 10(3), 200-211.

Gellin, A. (2003). The effect of undergraduate student involvement on critical thinking: A meta-analysis of the literature 1991-2000. Journal of College Student Development, 44(6), 746-762.

Goh, W. W. (2012). Can Wiki be used to facilitate critical thinking? A qualitative approach. International Journal of Engineering Pedagogy (iJEP), 2(4), 18.

Hennessy, S., McCormick, R., \& Murphy, P. (1993). The myth of general problem solving capability: Design and technology as an example. The Curriculum Journal, 4(1), 74-89.

Hsu, C-K., Hwang, G-J, Chuang, C-W., \& Chang, C-K. (2012). Effects on learners' performance of using selected and open network resources in a problem-based learning activity. British Journal of Educational Technology, 43(4), 606-623.

Ioannou, A., Brown, S. W., \& Artino, A. R. (2015). Wikis and forums for collaborative problem-based activity: A systematic comparison of learners' interactions. The Internet and Higher Education, 24, 3545.

ITS Education Asia. (2014). The skills of problem-solving. Retrieved Feb. 18, 2014 from: http://www.itseducation.asia/the-skills-of-problem-solving.htm

Jahng, N., Krug, D., \& Zhang, Z. (2007). Student achievement in online distance education compared to face-to-face education. European Journal of Open Distance and E-Learning. Retrieved December 1, 2014, from http://www.eurodl.org/materials/contrib/2007/Jahng_Krug_Zhang.htm

Jonassen, D. H. (1997). Instructional design models for well-structured and ill-structured problem-solving learning outcomes. Educational Technology Research and Development, 45, 65-95. 
Johnson, T. E., Archibald, T. N., \& Tenenbaum, G. (2010). Individual and team annotation effects on students' reading comprehension, critical thinking, and meta-cognitive skills. Computers in Human Behavior, 26, 1496-1507.

Keengwe, J. (2007). Faculty integration of technology into instruction and students' perceptions of computer technology to improve student learning. Journal of Information Technology Education, 6, 169180. Retrieved from http://www.jite.org/documents/Vol6/JITEv6p169-180Keengwe218.pdf

King, F. J., Goodson, L., \& Rohani, F. (1998). Higher order thinking skills: Definitions, strategies, assessment. A publication of the Educational Services Program (now known as the Center for Advancement of Learning and Assessment). Retrieved December 4, 2014 from www.cala.fsu.edu/files/higher order thinking skills.pdf

Koohang, A., \& Durante, A. (2003). Learners' perceptions toward the web-based distance learning activities/assignments portion of an undergraduate hybrid instructional model. Journal of Information Technology Education, 2, 105-113. Retrieved from http://www.jite.org/documents/Vol2/v2p105-113-78.pdf

Lai, C. Y., \& Wu, C. C. (2012). Supporting nursing students' critical thinking with a mobile web learning environment. Nurse Educator, 37(6), 235-236.

Lan, Y-F., Tsai, P-W., Yang, S-H., \& Hung, C-L. (2012). Comparing the social knowledge construction behavioral patterns of problem-based online asynchronous discussion in e/m-learning environments. Computers \& Education, 59, 1122-1135.

Land, S. M., \& Green, B. A. (2000). Project-based learning with the World Wide Web: A qualitative study of resource integration. ETR \&D, 48(1), 45-68.

Lewis, A., \& Smith, D. (1993). Defining higher order thinking. Theory into Practice, 32(3), 131-137.

Liu, M., Horton, L., Lee, J., Kang, J., Rosenblum, J., O’Hair, M., \& Lu, C. W. (2014). Creating a multimedia enhanced problem-based learning environment for middle school science: Voices from the developers. Interdisciplinary Journal of Problem-based Learning, 8(1), 4.

Means, B., Toyama, Y., Murphy, R., Bakia, M., \& Jones, K. (2009). Evaluation of evidence-based practices in online learning: A meta-analysis and review of online learning studies. US Department of Education. Retrieved December 1, 2014 from http://files.eric.ed.gov/fulltext/ED505824.pdf

Moore, P. (1995). Information problem solving: A wider view of library skills. Contemporary Educational Psychology, 20, 1-31.

Morin, D., Thomas, J. D.E., \& Saadé, R. G. (2012). Activities and resources in online learning: From a critical thinking view. In Proceedings of Informing Science \& IT Education Conference (InSITE) 2012 (pp. 597-602).

Morin, D., Thomas, J. D. E. \& Ly, S. (2014). The effect of delivery method on persistence, performance and perceptions. International Journal of Excellence in Education, 6(2), 1-10.

NC State Quality Enhancement Plan. (2014). Higher-order skills in critical and creative thinking. Retrieved December 11, 2014, from http://qep.ncsu.edu/wp-content/uploads/2014/01/qep-final.pdf

Oldenburg, N. L., \& Hung, W-C. (2010). Problem solving strategies used by RN-to-BSN students in an online problem-based learning course. Journal of Nursing Education, 49(4).

Pascarella, E. T. \& Terenzini, P. T. (2005). How college affects students: Volume 2, A third decade of research. San Francisco, CA: Jossey-Bass. Retrieved July 27, 2015, from http://campusclimate.ucop.edu/_common/files/pdf-climate/Distance_learning_articlePascarella_Terenzini.pdf

Pedaste, M., Pentjärv, H.-A., \& Sarapuu, T. (2003). Developing students' problem-solving skills by webbased simulation. Proceedings of the International Conference e-Learning in Science and Environmental Education. Tartu, Estonia, 88-91.

Phipps, R., \& Merisotis, J. (1999). The effectiveness of distance learning in higher education. Institute for Higher Education Policy, Washington, D.C. American Federation of Teachers, Washington, DC.; Na- 
tional Education Association, Washington, D.C., ERIC,1-49. Retrieved December 1, 2014 from: http://eric.ed.gov/?id=ED429524

Saadé, R. G., Morin, D., \& Thomas, J. D. E. (2012). Critical thinking in e-learning environments. Computers in Human Behavior, 28(5), 1608-1617.

Schmid, R. F., Bernard, R. M., Borokhovski, E., Tamim, R. M., Abrami, P. C., Surkes, M. A., \& Woods, J. (2014). The effects of technology use in postsecondary education: A meta-analysis of classroom applications. Computers \& Education, 72, 271-291.

Shen, P-D., Lee, T-H., \& Tsai, C-W. (2011). Applying blended learning with web-mediated self-regulated learning to enhance vocational students' computing skills and attention to learn. Interactive Learning Environments, 19(2), 193-209.

Sitzmann, T., Kraiger, K., Stewart, D., \& Wisher, R. (2006). The comparative effectiveness of web-based and classroom instruction: A meta-analysis. Personnel Psychology, 59(3), 623-664.

Song, L., Singleton, E. S., Hill, J. R., \& Koh, M. H. (2004). Improving online learning: Student perceptions of useful and challenging characteristics. Internet \& Higher Education, 7(1), 59-70.

Stewart, T. M., MacIntyre, W. R., Galea, V. J., \& Steel, C. H. (2007). Enhancing problem-based learning designs with a single e-learning scaffolding tool: Two case studies using challenge FRAP. Interactive Learning Environments, 15(1), 77-91.

Taplin, M. (2000). Problem-based learning in distance education: Practitioners' beliefs about an action learning project. Distance Education, 21(2), 278-299.

Tiruneh, D. T., Verburgh, A., \& Elen, J. (2014). Effectiveness of critical thinking instruction in higher education: A systematic review of intervention studies. Higher Education Studies, 4(1), 1-17.

Thomas, J. D. E. (2001). Technology integration and higher-order learning. Proceedings of the Conference in Advanced Technology in Education Conference, Banff, Calgary, Canada, May.

Thomas, J. D. E., \& Morin, D. (2010). Technological Supports for Onsite and Distance Education and Students' Perceptions of Acquisition of Thinking and Team-Building Skills. International Journal of Distance Education Technologies, 8(2), 1-13.

Thomas, J. D. E., Morin, D., \& Ly, S. (2014). Delivery method and persistence and performance. In Proceedings of World Conference on Educational Multimedia, Hypermedia and Telecommunications, Tampere, Finland, p. 1797-1801.

Tsai, C-W. \& Chiang, Y-C. (2013). Research trends in problem-based learning (PBL) research in elearning and online education environments: A review of publications in SSCI-indexed journals from 2004 to 2012. British Journal of Educational Technology, 44(6), 185-190.

Walker, R. (2014). Blended problem-based learning: Designing collaboration opportunities for unguided group research through the use of Web 2.0 tools. In V. Hodgson, M. de Laat, D. McConnell, \& T. Ryberg (Eds.), The design, experience and practice of networked learning (pp. 165-182). Springer International Publishing. 


\section{Biographies}

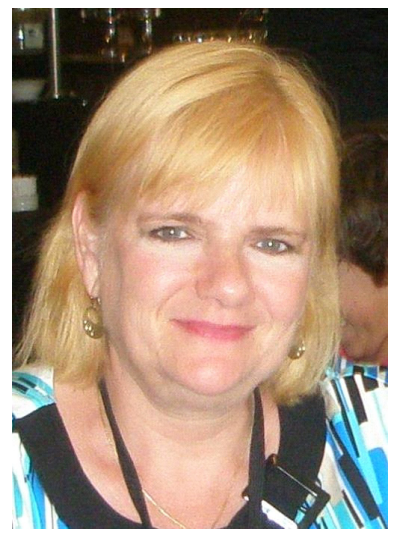

Danielle Morin is a Professor of Business Statistics in the department of Supply Chain and Business Technology Management in the John Molson School of Business at Concordia University in Montreal, Canada. She received her Ph.D. in Statistics from McGill University, Montreal, Canada. Her current research interests are focused on university education, namely the impact on technology integration and interdisciplinarity on student's learning. She teaches Business Statistics courses at both the Graduate and Undergraduate levels. She had been involved over thirteen years with Concordia University senior administration as Associate Dean and Vice-Provost. In 2005, she was awarded the YWCA Women of Excellence Award in Education and the Alumni Award for Teaching Excellence, as well as the first Concordia University Academic Leadership Award.

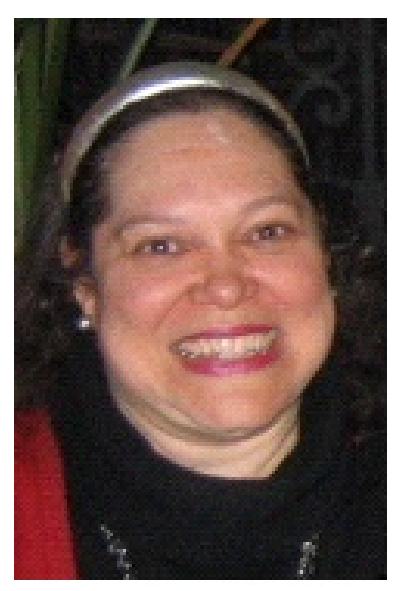

Jennifer D. E. Thomas is Professor of Information Systems at Pace University in New York City in the Seidenberg School of Computer Science and Information Systems. She received her Ph.D. and M.B.A. from Concordia University in Montreal, Canada, and her Bachelor of Commerce from McGill University, Montreal, Canada. Her research interests include Knowledge Management, User Experience - Human Factors, HumanComputer Interaction, Multimedia, and the Impact of Technology Integration on Learning. Her teaching includes onsite and online courses at both the graduate and undergraduate levels Introduction to Information Systems Concepts, User Experience - Multimedia and Human-Computer Interaction, Distributed Computing, Research Methodology, Business Telecommunications, and has co-taught an undergraduate Beowulf and Multimedia course with the English Department.

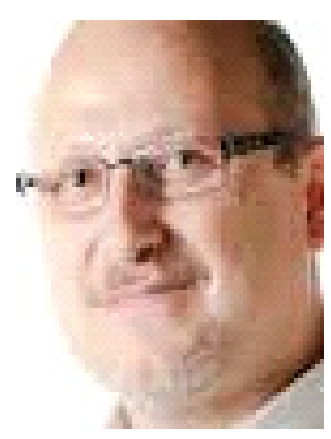

Dr. Raafat George Saadé has been teaching in the faculty since 1998. He obtained his Ph.D. in 1995 (Concordia University) after which he received the Canadian National Research Council postdoctoral scholarship, which he completed at McGill University in Montreal. Dr. Saadé has published in journals such as Information \& Management, Decisions Sciences, and Expert Systems with Applications. His research interests include informationsystems-driven organizational change, supply chain of digital information products and change management. 